those who see the merits. It was also to underline the merits to those who might not readily see them.

The composition of general professional training in psychiatry deserves continuing debate. It may no longer be appropriate just to think in terms of a range of apparently equivalent posts in specialities. Psychiatrists need, we suggest, to learn about the context in which they practise (e.g. general practice placements and community psychiatry posts). They also need to experience how psychiatry is applied across the life-span and appreciate the impact of age-related change (e.g. child and adolescent and old age psychiatry). They may also need to develop skills within specific posts (e.g. psychotherapy and substance abuse).

Dr Sullivan asks if six months in general practice is more valuable than, say, six months in child psychiatry. He asks if anyone has put it to the Professor of Child Psychiatry at St George's. TB did put it to PH. His reply was "I think that all psychiatrists should have at least six months experience in child and adolescent psychiatry. I actually think it is more important than general practice experience!". But then he would, wouldn't he?

TOM BURNS and PETER D. HILL, St George's Hospital Medical School, Jenner Wing, Cranmer Terrace, London SW17 ORE

\section{A variant of Capgras syndrome}

Sir: We would like to describe a variant of Capgras syndrome which is slowly permeating the Royal College of Psychiatrists. This causes persons with the forename Greg, and triple syllable surnames ending in -son, to be viewed by the College as one person. One of us should have recognised the onset when, as a jobbing child psychiatrist, with a short letter published in World Medicine, he kept being congratulated on his considerable publications. Within five years the President's office was affected, communications confusing one with the other, and then one being introduced to the President's spouse as the other. Sadly the affliction seems now to have reached one of our home divisions, for in the report of the North East and Midlands
Division debate (Tyrer \& Wallis, 1994) "Professor Greg Wilkinson cited ..... The Greg who was there was Greg Richardson and we do not believe we speak for each other. Is it aetiologically significant that one of the authors of the report on the above debate is a monozygotic twin of a Professor of Psychiatry in London, or does the College just like all its Gregs in one basket? Suggestions for management of this condition will be gratefully received.

TYRER, S. \& WALLIS, G. (1994) Cost benefit in psychiatry - a debate. Psychiatric Bulletin. 18, 298-299.

GREG WILKINSON, Professor of Psychiatry, London, and GREG RICHARDSON, Child and Adolescent Psychiatrist, York.

Sir: I take full responsibility for this error and apologise unreservedly. The psychopathology, however, should be attributed not to Joseph Capgras but Sigmund Freud (1914), the similarities of names and hovering monozygosis having induced "a disturbance of the attention through a strange obtruding thought".

Freud, S. (1914) Psychopathology of Everyday Lfe. Harmondworth: Penguin (1940 reprint).

GeOFFrey WALlis, Stockton Hall Hospital, York YO3 9VN

\section{Association of Bangladeshi Psychiatrists}

Sir: This organisation will be set up to provide a forum for the exchange of information and ideas and to bring together the views and experiences of colleagues working in psychiatry in the U.K.

The professional and educational remit of the organisation will be to examine the possibility of providing final year students' elective placements, participation in the Overseas Doctors Training Scheme and help in such areas as preparation of curriculum vitae and examination techniques.

A membership drive is being launched. Enquiries to:

DR N. AHMED, Association of Bangladesht Psychiatrists, 17 Farndale Avenue, Southbents, Sunderland, Tyne and Wear SR6 8BH (telephone 091 5292123). 